\section{The Art of Science}

From Stonehenge to Modern Cosmology. By Fred Hoyle. Pp. 96. (W. H. Freeman: San Francisco and Reading, March 1973.) $£ 2.10$.

AN art historian from Vienna once gave me his personal view of contemporary art-and here I extrapolate freely from memory-that the art of the times is science. He held that some day we will look back on our present science as an essentially religious enthusiasm and the cyclotrons and telescopes that did this science as representative works of folk art.

It is fascinating to read, then, Fred Hoyle's absorbing analysis of Stonehenge as an ancient astronomical observatory. It feels right that the stone age builders of this monument, inextricably close to their environment, should be strongly aware of the eclipses of the Sun and the Moon. It is an intellectual pleasure to follow Hoyle's reconstruction of how the post holes and sighting lines enabled eclipses to be predicted. It was an elevating thought for me to consider that these ancients, with their stone age orrery, had probably a simple, accurate grasp of the spatial relationships of their nearby, celestial neighbours.

But then the question arises: Why did the functions of Stonehenge I decay? Did the early Britons find the smelting of metals more useful than the predicting of eclipses? It now becomes clear that of the four short lectures that comprise this ninety-three-page book, the one on Stonehenge should have come first. The one that is actually first, "Science and Society in Modern Times", should have come second because it raises the question of what makes a society rise and decline. Hoyle notes a tension between science and society. He notes the obvious fact that science, technology and its long range consequences are not deeply understood by many politicians. Hence science is often applied destructively rather than constructively to society. But he does not discuss what is, to me, the more crucial point; that is, the effect of society on scientists. Surely scientists reflect the competitiveness and insecurity of their milieu. They manoeuvre for pre-eminence, squabble over marginal doctrinal issues, and only unite to suppress the threat of new ideas. The real tragedy-beyond the fact that science is not much fun under these conditions-is that science is then misapplied by shortsighted or unscrupulous people from other sectors of society. The scientists have no effective chance of ensuring that their product is used constructively because they are totally disunited.

If we were ever to live in a healthy, friendly, intelligent world, perhaps the last two chapters in this book would furnish us a glimpse of the kind of activities we would be engaged in. The broadest possible questions are addressed-like the distances of quasars and galaxies, the nature of mass, the phenomenon of seafloor spreading in the Earth. Hoyle faces the hard obser vational evidence for discrepancies in the conventional cosmology and tries to gain understanding by connecting inferences from many fields of astronomy, physics, and science. Needless to say, his suggestions are considered contro versial. It is often said about someone who is obviously very bright, but clearly a non-conformist that, well, maybe he is incorrect but he is valuable because he stimulates thought. That is not quite the point. On many of the issues raised in this book there are right and wrong answers. At least there are some answers that are a good deal more correct than others. About only one thing can we be fairly certain and that is that the status quo is incomplete. If we have much of a future, our current understanding of reality will eventually appear extremely primitive. Which are now the most correct answers?

If we progress in our understanding it will have to be through an unprejudiced awareness of our environment. Perhaps the builders of Stonehenge I had such a harmonious attitude toward their surroundings. Perhaps some day we will pursue fundamental questions such as what is the nature of the universe in a more leisurely and cooperative fashion, like an art. And perhaps that will be the most rigorous analysis of all.

HALTON ARP

\section{Buffalo}

The Time of the Buffalo. By Tom $\mathrm{McHugh}$ with the assistance of Victoria Hobson. Pp. xxiv $+339+x i$. (Alfred Knopf: New York, December 1972.) $\$ 10$.

THIS is a long, in parts detailed but for the most part readable book about both North American subspecies of the socalled buffalo-Bison bison bison, the plains buffalo, and $B$. bison athabascae, the wood buffalo. To a much lesser extent it is also about their ancestors and near relatives. It is not clear, however, what readership the author had in mind when writing it, although the somewhat vague, rather nostalgic title seems to suggest that a wide market is envisaged. This lack of focus may be a consequence of the author's three professional interests: research zoologist with a special interest in animal ecology and wildlife management; author; and photographer for several of Walt Disney's True Life Adventure films, including The Vanishing Prairie. It is most certainly not a book for the anatomist, physiologist or palaeontologist and scholars interested in the historical aspects of the buffalo will find that it lacks the depth of Frank G. Roe's The North American Buffalo: a Critical Study of the Species in the Wild State (University of Toronto Press, Toronto, 1970).

Much of the book is concerned with the Indians' use of and attitude towards the buffalo at and immediately after the period of first white contacts but it is not a significant contribution to cultural anthropology. The author's real contribution is that, working as an animal ecologist, he has spent considerable time observing at close range the present-day herds in Yellowstone National Park, Wind Cave National Park, the Wichita Wildlife Refuge, the National Bison Range and the Crow Reservation. His objective in doing so was to try to answer some of the "legacy of questions" left by the "vast literature on the beast", not by a further re-sifting of the literature but by personal observations. How did hidehunters manage to kill large numbers from a single group without frightening the survivors? Did the vast herds wander erratically or make precise annual migrations? Did vast numbers actually die in blizzards, drownings, quicksands and prairie fires? It is from his own observations that the author contributes most in attempting to answer questions like these and it is when he writes of these observations that he is at his most compelling.

Not surprisingly, in the light of the author's professional experience as a photographer, the book is illustrated with some excellent monochrome prints of buffalo in action: at birth and play; wallowing and fighting; and being lured into traps by the author's successful application of the techniques employed by Indian decoys. One would have welcomed more of these, even if it had been at the expense of some of the reproductions of nineteenth century etchings, paintings and photographs of buffalo hunts and hunting techniques. Four pages of maps are given pride of place at the front of the book. These are useful but the two showing the whole of North America lack clarity. There 